
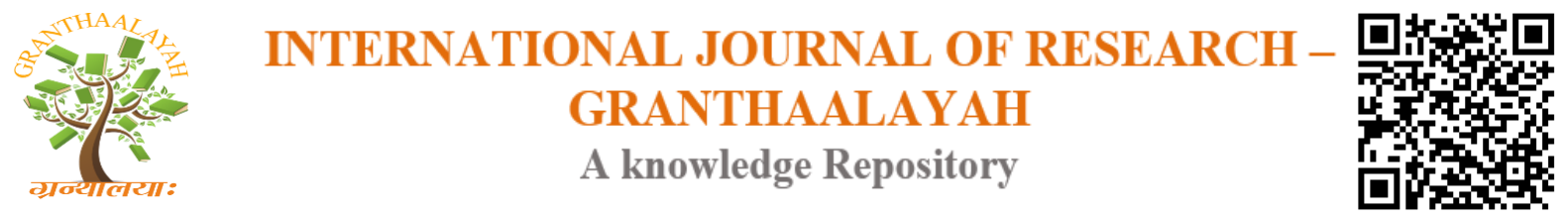

Management

\title{
FACTORS AFFECTING BRAND LOYALTY IN THE FOOTWEAR INDUSTRY - A STUDY OF LUDHIANA DISTICT
}

\author{
Rajdeep Singh ${ }^{* 1}$ \\ ${ }^{* 1}$ Research Scholar, University School of Applied Management, Punjabi University, Patiala, \\ INDIA
}

DOI: https://doi.org/10.29121/granthaalayah.v4.i6.2016.2647

\section{ABSTRACT}

The dynamic competitive environment has changed the way the businesses were run in the past. The increased awareness of the customers along with increase in the number of options available to them has completely revolutionized the marketing task. In the current scenario a greater need is felt for long term relationships with the customers so as to enjoy repeat sales. The business organizations these days are laying focus on enhancing the brand loyalty among the consumers to reap the benefits of repeat sales. The present study, therefore, is an endeavor to investigate the factors that affect brand loyalty in the footwear industry. Simultaneously an attempt has been made to identify the most sought after brand in the footwear industry. A sample of 100 respondents was selected from the Ludhiana region. Statistical techniques of correlation and multivariable regression were used. The results depicted that out of the total fourteen identified factors, twelve factors had significant relationship with brand loyalty. Proper pricing techniques and customer satisfaction were the dominant variables in affecting brand loyalty towards a footwear brand.

Keywords:

Brand Loyalty, Footwear Industry, Multiple Regression Analysis.

Cite This Article: Rajdeep Singh, "FACTORS AFFECTING BRAND LOYALTY IN THE FOOTWEAR INDUSTRY - A STUDY OF LUDHIANA DISTICT" International Journal of Research - Granthaalayah, Vol. 4, No. 6 (2016): 139-149.

\section{INTRODUCTION}

The advent of new technology and new modes of communication along with modern lifestyle fueled by increased incomes have resulted in the awareness of the customers in all the industries. The dynamic competitive environment has changed the way the businesses were run in the past. The increased awareness of the customers along with increase in the number of options available to them has completely revolutionized the marketing task. In the current scenario a greater need is felt for long term relationships with the customers so as to enjoy repeat sales. The business organizations these days are laying focus on enhancing the brand loyalty among the consumers 
to reap the benefits of repeat sales. It has led to a situation where long term customer relationship is the only means to ensure sustainability. Therefore brand loyalty has emerged as an important area for the marketers to ensure the long term survival of the business organization. The managers these days have the responsibility of framing long term strategies to promote brand loyalty among the customer.

(Assael 1998) defined brand loyalty, "as a favorable attitude of the customer towards a brand which is a result of consistent purchase of the brand over time". In other words brand loyalty is nothing but a realization by the customer that a particular brand provides him with maximum satisfaction. It is the extent of trust and belief on a particular brand that is represented by the repeat purchases of the brand by the customers despite the knowledge and availability of the other brands existing in the market. Therefore it is the discretion on the part of the customer to purchase a specific brand repeatedly in a particular product category. Brand loyalty is dependent upon the needs and aspirations of a customer from the particular brand. If the customer believes or feels that his requirements and needs are being satisfied by a particular brand then he/she indulges themselves in repeat purchases of the very same brand in the same product category.

The expectations, requirements and aspirations of the consumers have been continuously evolving through the ages. In the present scenario the scope for brand loyalty has increased as the consumers have become more brand conscious and try to identify them with a particular or specific brand. Apart from clothing, the footwear industry is the one that is affected by the fashion waves existing in the society at a time. The increased globalization has led to proliferation of a number of brands in the footwear industry and has thus intensified the competition like never before. Therefore the companies are loaded with an important task to maintain long term healthy relationships with their clients so as to ensure their long term sustainability through enhanced brand loyalty.

There are innumerable factors that can affect the brand loyalty for a product among the customers. Price, Style, durability, quality of material used, fashion waves etc. are some of the few factors that can affect brand loyalty. The present study is an endeavor to identify the important factors that have an impact on the brand loyalty of the customers.

The top 15 brand for footwear industry in India are as follows:

- Bata

- Nike

- Reebok

- Liberty

- Adidas

- Paragon

- Woodland

- Puma

- Red Tape

- Relaxo

- Action

- Lotto

- Valentino 
- Hitz

- Lancer

\section{THEORETICAL BACKGROUND AND HYPOTHESIS DEVELOPMENT}

(Kirwa et al. 2013) carried out a research work on the topic, "Determinants of Brand Loyalty and Product Quality of Soft Drink Consumers". The purpose of the study was to identify and simultaneously compare the loyalty determinants among the consumers of soft drinks in two different countries of India and. The sample comprised of the university going students among both the countries. The findings depicted that in Kenya parents had a huge influence on the soft drink consumption decision. However in India the peer group was the one that affected the soft drink consumption decision.

(Muhammad et al. 2013) carried out a research titled, "The impact of the perceived quality, and Customer Satisfaction, Brand Trust and Contextual factors on Brand loyalty." The research was carried out in Pakistan with the purpose of knowing the impact of perceived quality, brand trust and customer satisfaction on brand loyalty. The respondents comprised of the students, employees and businesspersons. The findings of the study depicted that brand trust was the most important factor in influencing brand loyalty. The other two factors of perceived quality and customer satisfaction were also significant.

Sirchuk Jennifer (2012) carried out a research project titled "Building Brand Loyalty through Youth Consumers and the use of Grass Roots Consumer marketing". The purpose of the research project was to identify the different methods or ways in which an organization can enhance its brand loyalty. The findings of the study revealed that branding can be used by the companies to enhance brand loyalty among the consumers. Different methods for branding such as visual consistency, quality performance and developing long term healthy relationships can be used to enhance loyalty.

Haghighi Mohammad, Dorosti Ali, RahnamaAfshin, Hoseinpour Ali (2012) carried out a study titled, "Evaluation of factors affecting customer loyalty in the restaurant industry". The objective of the study was to identify and investigate different factors influencing brand loyalty in the restaurant sector. The sample comprised of 268 customers. The results revealed that food quality is the most influential factor that affects customer satisfaction and trust in the restaurant industry. Also service and food quality, environment and strategic pricing influences the customer's loyalty in case of restaurant industry.

(Allender and Richards 2009) conducted a study titled "Measures of Brand Loyalty". The objective of the research was to investigate the relationship between brand loyalty and the pricing strategy. The findings of the study depicted that in the RTE cereal category the level of brand loyalty was very high. It also highlighted the negative relationship between the strength of the brand and the frequency of price promotions at the retail level.

(Mohammad et al. 2009) conducted a research study with the objective of finding out the relationship between brand credibility and customer loyalty. The findings of the study confirmed 
the existence of a relationship between customer loyalty and brand credibility. However no such relationship exists between customer loyalty and customer satisfaction.

(Ngina 2007) conducted a research project on the topic "Factors determining Brand Loyalty: The case of Commercial Banks in the Westland area of Nairobi". The sample comprised of 200 respondents selected from different branches of the banks in the Westland area. The findings revealed that the most loyal customers of the banks were the employees of the private companies. The loyalty of the customers was also dependent upon the education level of the customers as the most loyal customers were highly educated. Prompt service, location, willingness of employees to help customers, operating hours, and availability of ATM outlets were the most highly rated factors by the respondents in that order.

(Smith and Wright 2004) conducted a research study in the computer industry. The researchers used brand image, product quality, service quality, and firm viability as determinants of customer loyalty so as to predict sales growth rate and return on assets. The study pointed out that service quality and firm viability are important factors but brand image was not significant. Product quality was negatively associated with customer loyalty.

\section{HYPOTHESIS FORMULATION}

The following hypothesis has been formulated based upon the literature review

$\mathbf{H}_{\mathbf{0 1}}$ : There is no relationship between brand loyalty and trendy \& fashionable designs of the brand.

$\mathbf{H}_{\mathbf{0 2}}$ : There is no relationship between brand loyalty and good functional quality of the brand.

$\mathbf{H}_{\mathbf{0 3}}$ : There is no relationship between brand loyalty and availability of brand in various sizes \& colours.

$\mathbf{H}_{\mathbf{0 4}}$ : There is no relationship between brand loyalty current pricing strategies of the brand.

$\mathbf{H}_{\mathbf{0 5}}$ : There is no relationship between brand loyalty and increase in price of the brand.

$\mathbf{H}_{\mathbf{0 6}}$ : There is no relationship between brand loyalty and number of outlets \& their accessibility.

$\mathbf{H}_{07}$ : There is no relationship between brand loyalty and interior environment of the outlet.

$\mathbf{H}_{\mathbf{0 8}}$ : There is no relationship between brand loyalty and well trained \& helpful salesperson.

$\mathbf{H}_{09}$ : There is no relationship between brand loyalty and prompt service at the outlet.

$\mathbf{H}_{\mathbf{1 0}}$ : There is no relationship between brand loyalty brand \& image of the brand.

$\mathbf{H}_{11}$ : There is no relationship between brand loyalty attractive advertisements by the brand.

$\mathbf{H}_{12}$ : There is no relationship between brand loyalty and recommending the brand to other people.

$\mathbf{H}_{13}$ : There is no relationship between brand loyalty and reliability of the products of the brand.

$\mathbf{H}_{14}$ : There is no relationship between brand loyalty and satisfactory experience with the brand.

\section{RESEARCH METHODOLOGY}

\subsection{RESEARCH DESIGN}

Descriptive research design has been used for the study as it aims at describing the relative importance of the selected factors that may affect brand loyalty in the footwear industry. 


\subsection{OBJECTIVES}

1) To identify the most preferred brand among the selected brands in the footwear industry.

2) To study the relative impact of selected factors on the brand loyalty in the footwear industry.

\subsection{SAMPLE SIZE}

The sample size for the present study has been limited to 100 respondents.

\subsection{SAMPLING TECHNIQUE}

Convenience sampling technique has been used in this study.

\subsection{TYPE OF DATA}

Primary data was used in this study.

\subsection{TOOLS FOR DATA COLLECTION}

A well-structured questionnaire based on five point Likert Scale was used in the study.

\subsection{STATISTICAL TOOLS AND TECHNIQUES}

Descriptive statistics was used to analyze the respondent profile and also to identify the most preferred brand among the selected brands in the footwear industry. Correlation analysis was used to find the relationship between the brand loyalty and other independent factors. Then multiple regression analysis was applied on those variables which had relationship with brand loyalty (as per the results of correlation analysis).

In the present study only few brands were considered which were popular in the Ludhiana region. These are as follows:

- Reebok

- Adidas

- Puma

- Bata

- Liberty

\section{DATA ANALYSIS AND INTERPRETATION}

\subsection{PROFILE OF RESPONDENTS}

Table 1 depicts the profile of the respondents that were included in the sample. Among the 100 respondent $61 \%$ of the respondents were males and the remaining $39 \%$ were females. The maximum number of respondents $(51 \%)$ was in the age group of $20-25$ years. The maximum number of respondents was students $(55 \%)$. From the collected data it was found that since most 
of the respondents were students so they had no income. The most preferred brand in the footwear industry is Reebok as $36 \%$ of the total respondents prefer it.

Table 1: Profile of Respondents

\begin{tabular}{|c|c|c|c|}
\hline CATEGORY & OPTIONS & FREQUENCY & PERCENTAGE \\
\hline \multirow{3}{*}{ GENDER } & Male & 61 & 61 \\
\hline & Female & 39 & 39 \\
\hline & Total & 100 & 100 \\
\hline \multirow{5}{*}{ AGE (in years) } & $20-25$ & 51 & 51 \\
\hline & $26-30$ & 28 & 28 \\
\hline & $31-35$ & 15 & 15 \\
\hline & $36-40$ & 6 & 6 \\
\hline & Total & 100 & 100 \\
\hline \multirow{5}{*}{ OCCUPATION } & Student & 55 & 55 \\
\hline & Businessman & 9 & 9 \\
\hline & Government Employee & 7 & 7 \\
\hline & Private Employee & 29 & 29 \\
\hline & Total & 100 & 100 \\
\hline \multirow{6}{*}{$\begin{array}{l}\text { MONTHLY INCOME } \\
\text { (in Rs.) }\end{array}$} & Nil & 46 & 46 \\
\hline & Below 15000 & 8 & 8 \\
\hline & $15000-25000$ & 14 & 14 \\
\hline & $25000-35000$ & 8 & 8 \\
\hline & Above 35000 & 24 & 24 \\
\hline & Total & 100 & 100 \\
\hline \multirow{6}{*}{ PREFFERED BRAND } & Reebok & 36 & 36 \\
\hline & Adidas & 18 & 18 \\
\hline & Puma & 12 & 12 \\
\hline & Bata & 25 & 25 \\
\hline & Liberty & 13 & 13 \\
\hline & Total & 100 & 100 \\
\hline
\end{tabular}

\section{CRONBACH ALPHA RESULT}

The value of cronbach's alpha is 0.854 . Therefore the internal consistency of the scale is very high.

Table 2: Cronbach Alpha Result

Reliability Statistics

\begin{tabular}{|l|l|l|}
\hline Cronbach's Alpha & $\begin{array}{l}\text { Cronbach's Alpha Based on N of Items } \\
\text { Standardized Items }\end{array}$ & \\
\hline .854 & .858 & 15 \\
\hline
\end{tabular}




\section{CORRELATION ANALYSIS RESULTS}

$\mathrm{H}_{01}$ : Relationship between Brand Loyalty and Trendy \& Fashionable designs of the brand. The result of the correlation test reveals that correlation between these two variables is 0.118 and it was not found to be significant at 0.05 levels. Hence the hypothesis that there is no relationship between Brand Loyalty and Trendy \& Fashionable designs of the brand is accepted.

\section{$\mathrm{H}_{02}$ : Relationship between Brand Loyalty and Good functional quality of the brand.}

Correlation results of Brand loyalty and good functional quality of the brand reveals that there is moderate positive relationship between these variables with $\mathrm{r}=.437$ and significant value of $\mathrm{p}=$ .000.Hence the hypothesis that there is no relationship between Brand Loyalty and Good functional quality of the brand is rejected.

$H_{03}$ : Relationship between Brand Loyalty and availability of brand in various sizes and color.

Availability of brand in various sizes and color was found to be positively related with brand loyalty. The correlation value between these variables is .307 with significant value of $(p=.002)$. This reveals that there is a weak relationship between these variables. Hence the hypothesis that there is no relationship between Brand Loyalty and availability of brand in various sizes and color is rejected.

$\mathrm{H}_{04}$ : Relationship between Brand Loyalty and correct current pricing strategy of the brand.

After computing correlations of Brand Loyalty and Current Pricing strategy of the brand it was found that current price of the brand is positively \& moderately correlated with brand loyalty with correlation value of $r=0.453$ at significant value of $p=.000$. Hence the hypothesis that there is no relationship between Brand Loyalty and current pricing strategy of the brand is rejected.

\section{$\mathrm{H}_{05}$ : Relationship between Brand Loyalty and increase in price of the brand.}

To see the relationship between brand loyalty and price increase, the results of the correlation test reveal a weak correlation value of 0.337 with significant value of $p=.001$. This reveals that if price increase up to some extent, the customer would still prefer the same brand. Hence the hypothesis that there is no relation of price increase and customer buying the same brand i.e. being brand loyal is rejected.

\section{$\mathrm{H}_{06}$ : Relationship between Brand Loyalty and number of outlets and their accessibility.}

The result of the correlation test reveals that correlation between these two variables is 0.129 and it was not found to be significant at 0.05 levels. Hence the hypothesis that there is no relationship between Brand Loyalty and number of outlets and their accessibility is accepted. 
$\mathrm{H}_{07}$ : Relationship between Brand Loyalty and attractive interior environment of the outlet. Attractive interior environment of the outlet was found to be positively related with brand loyalty. The correlation value between these variables is .261 with significant value of $(\mathrm{p}=.009)$. This reveals that there is a weak relationship between these variables. Hence the hypothesis that there is no relationship between Brand Loyalty and attractive interior environment of the outlet is rejected.

$\mathrm{H}_{08}$ : Relationship between Brand Loyalty and well trained \& helpful salesperson at the outlet.

Relationship between well trained \& helpful salesperson at the outletwasfound positive but weakly related to brand loyalty of consumers. Value of correlation of was $r=0.285$, with significant value of $\mathrm{p}=.004$. Therefore correlation result is not compatible with our hypothesis, which assumed that, there is no relationship between Brand Loyalty and well trained \& helpful salesperson at the outlet. Hence the hypothesis that there is no relationship between Brand Loyalty and well trained \& helpful salesperson at the outlet is rejected.

$\mathrm{H}_{09}$ : Relationship between Brand Loyalty and prompt service at the outlet.

Correlation results of Brand loyalty and prompt service at the outlet reveals that there is weak positive relationship between these variables with $r=0.325$ and significant value of $p=.001$. Hence the hypothesis that there is no relationship between Brand Loyalty and prompt service at the outlet is rejected.

\section{$H_{10}$ : Relationship between Brand Loyalty and brand image.}

After computing correlations of Brand Loyalty and Brand Imageit was found that brand image is positively \& moderately correlated with brand loyalty with correlation value of $r=0.383$ at significant value of $p=.000$. Hence the hypothesis that there is no relationship between Brand Loyalty and brand image is rejected.

$\mathrm{H}_{11}$ : Relationship between Brand Loyalty and informative \& attractive advertisements by the brand.

Informative \& attractive advertisements by the brand werefound to be positively related with brand loyalty. The correlation value between these variables is 0.214 with significant value of $(p=.032)$. This reveals that there is a weak relationship between these variables. Hence the hypothesis that there is no relationship between Brand Loyalty and informative \& attractive advertisements by the brand is rejected.

$\mathrm{H}_{12}$ : Relationship between Brand Loyalty and recommending the brand to others.

Relationship between recommending the brand to others was found positively related to brand loyalty of consumers. Value of correlation of was $r=0.321$, with significant value of $p=.001$. Therefore correlation result is not compatible with our hypothesis, which assumed that, there is no relationship between Brand Loyalty and recommending the brand to others. Hence the hypothesis that there is no relationship between Brand Loyalty and recommending the brand to others is rejected. 
$\mathrm{H}_{13}$ : Relationship between Brand Loyalty and reliable products of the brand.

The results of the correlation analysis revealed a correlation value of 0.294 with significance value of 0.003 . This means that if the consumer feels the brand is reliable then he would prefer that brand in future as well. Hence the hypothesis that there is no relationship between Brand Loyalty and reliable products of the brand is rejected.

\section{$H_{14}$ : Relationship between Brand Loyalty and customer experience with the brand.}

Customer's overall experience with the brand was found to be strongly correlated with brand loyaltyhaving correlation value of 0.605 with significance value of 0.000 . This means that more is the customer satisfaction more is brand loyalty i.e. the customer would prefer the same brand in future as well. Hence the hypothesis that there is no relationship between Brand Loyalty and satisfactory experience with the brand is rejected.

\section{REGRESSION ANALYSIS RESULTS}

Table 3: Model Summary

\begin{tabular}{|l|l|l|l|l|}
\hline Model & R & R Square & Adjusted R Square & $\begin{array}{l}\text { Std. Error of the } \\
\text { Estimate }\end{array}$ \\
\hline 1 & $.708^{\mathrm{a}}$ & .502 & .433 & .63544 \\
\hline
\end{tabular}

a. Predictors: (Constant), Satisfaction, InformativeAdvertisement, PricingStrategySatisfactory, TrainedSalesPerson, VariousSizeAndColour, Recommend ToOthers, PriceIncreaseEffect, BrandImage, Reliability, GoodFunctionalQuality, InteriorEnvironment, PromptService

Table 4: Coefficients ${ }^{\mathrm{a}}$

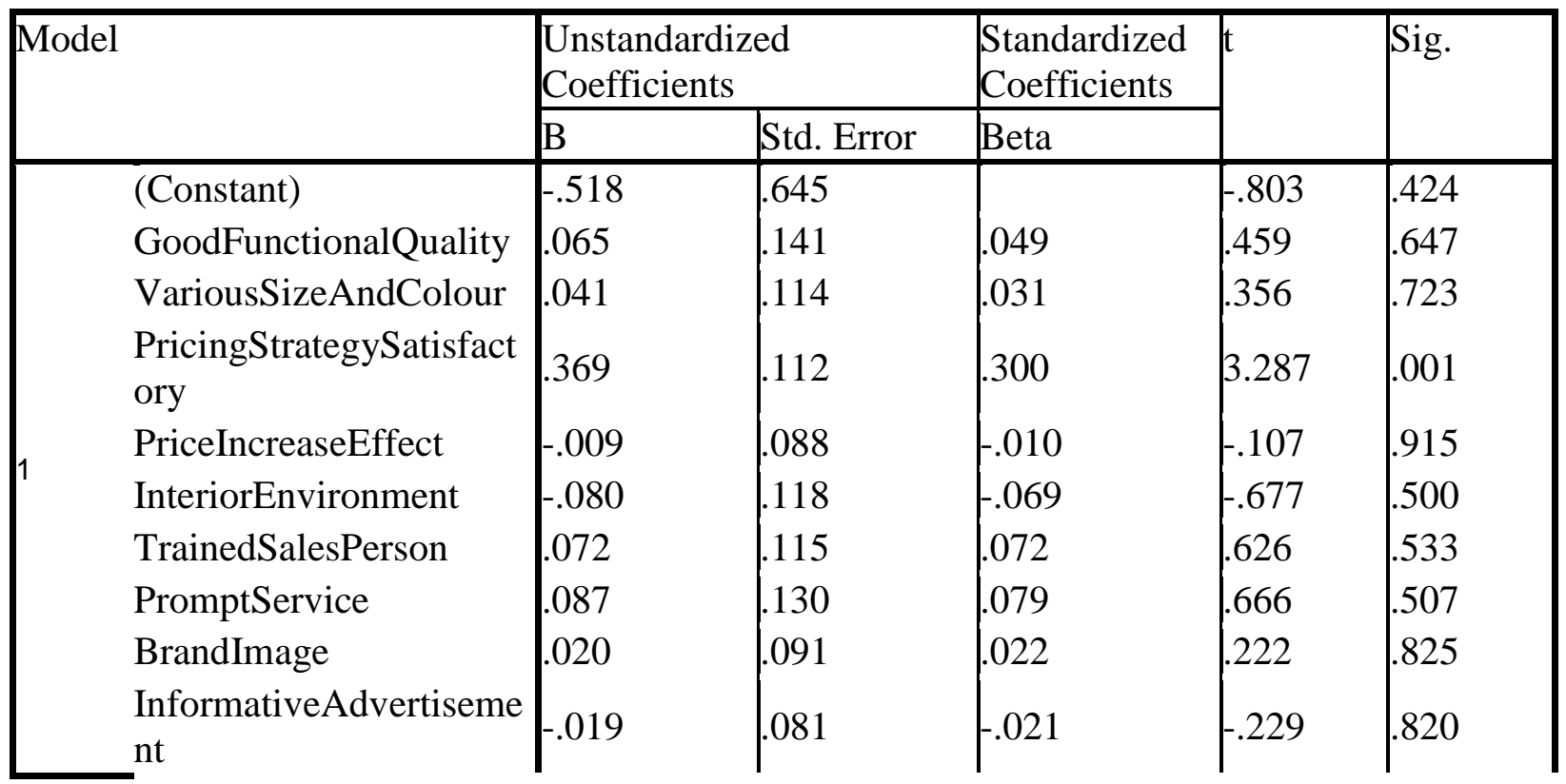




\begin{tabular}{|l|l|l|l|l|l|}
\hline Recommend ToOthers & .090 & .096 & .089 & .940 & .350 \\
Reliability & -.241 & .146 & -.172 & -1.651 & .102 \\
Satisfaction & .719 & .147 & .542 & 4.876 & .000 \\
\hline
\end{tabular}

a. Dependent Variable: BrandLoyalty

Table 3 depicts that the value of adjusted $\mathrm{R}$ square is .433 which means that $43.3 \%$ of the variation in the dependent variable is explained by the independent variables.

Table 4 depicts that prompt service is the most important factor that affects brand loyalty as standardized beta value is .079 .

\section{CONCLUSION}

The study intended to find out the factors that affect the brand loyalty in case of footwear industry. On the basis of literature review, fourteen factors were identified as important determinants of brand loyalty. Using these factors a structured questionnaire was prepared to record the customer response. The results of the correlation analysis reveal that among the fourteen variables, twelve variables had relationship with brand loyalty. Two variables namely trendy $\&$ fashionable designs of the brand and number of outlets $\&$ their accessibility showed no relationship with brand loyalty. The current study also highlighted that satisfactory pricing strategy and customer satisfaction are the two most important determinants of brand loyalty. But the study was limited to specificregion and few respondents. So there is scope for further research in this area.

\section{REFERENCES}

[1] ClotteyToyin A., Collier David A., Stodnick Michael (2008).Drivers of Customer Loyalty in a Retail Store Environment. Journal of Service Science, 1(1), 35-48.

[2] Haghighi Mohammad, Dorosti Ali, RahnamaAfshin, Hoseinpour Ali (2012). Evaluation of factors affecting customer loyalty in the restaurant industry. African Journal of Business Management, 6 (14), 5039-5046.

[3] K.M Jairo, Nair Chandrasekeran, OderaOdhiambo, Ogutu Martin (2013). Determinants of Brand Loyalty and Product Quality of Soft Drink Consumers. Asian Journal of Business and Management, 1 (1), 8-13.

[4] Kinuthia Lydia N., MburuguKeren G., Muthomi Helen N., Mwihaki Mary (2012). Factors influencing brand loyalty in sportswear among Kenyan University students: The case of swimmers. Asian Journal of Social Sciences \& Humanities, 1(4), 223-231

[5] Lau Mei - mei et-al (2006). The brand loyalty of sportswear in Hong Kong. Journal of Textile and Apparel, Technology and Management, 5 (1), 1-13.

[6] Mise Jairo Kirwa, Nair Chandersekeran, OderaOdhiambo, Ogutu Martin (2013). Determinants of Brand Loyalty and Product Quality of Soft Drink Consumers. Asian Journal of Business and Management, 1(1), 8-13

[7] NezakatiHossein et-al (2011).Factors influencing customer loyalty towards fast food restaurants. International Conference on Sociality and Economics Development, 10, 1216.

[8] Rizwan Muhammad, Usman Ali, Hussain Tajamul, ShafiqAkasha, Rauf Sana, AyazQuratUlAian (2013). The Impact of the Perceived Quality, Customer Satisfaction, 
Brand Trust and Contextual Factors on Brand Loyalty. International Journal of Research in Commerce \& Management, 4 (3), 83-90.

[9] Shokati Samira et al (2013). Effective Factors on Customers Brand Loyalty in Iranian Banks. Singaporean Journal of Business Economics, and Management Studies, 1(9), 3338

[10] Sondoh Stephen L. et al (2007).The Effect of Brand Image on Overall Satisfaction and Loyalty Intention in the Context of Color Cosmetic. Asian Academy of Management Journal, 12(1), 83-107

[11] WelCheAnizaBintiChe et-al (2011).Factors Affecting Brand Loyalty: An Empirical Study in Malaysia. Australian Journal of Basic and Applied Sciences, 5(12), 777-783. 